\title{
A Historical Note on Hodgson v. Bowerbank
}

\author{
Dennis J. Mahoney $\dagger$
}

After Marbury v. Madison ${ }^{1}$ the Supreme Court did not hold another federal law unconstitutional until the Dred Scott decision. ${ }^{2}$ This at least is the received version of American constitutional history, reported in textbooks and popular works alike, by lawyers, ${ }^{3}$ political scientists, ${ }^{4}$ and historians; ${ }^{5}$ this is what one

$\dagger$ Assistant Editor, Encyclopedia of the American Constitution, and Lecturer in Political Science, California State College, San Bernardino. I would like to thank Professors Leonard W. Levy and Kenneth L. Karst, Editor and Associate Editor of the Encyclopedia of the American Constitution, who set me the task of discovering what really happened in Hodgson v. Bowerbank, and who offered advice and assistance. I would also like to thank Professor William Cohen, who read and commented on an early draft.

15 U.S. (1 Cranch) 137 (1803).

2 Dred Scott v. Sandford, 60 U.S. (19 How.) 393 (1857).

3 See, e.g., A. Bickel, The Least Dangerous Branch 14 (1962); J. Choper, Judicial Review and the National Political Process 386 (1980); W. O. Douglas, An Almanac of Liberty 227 (1954); C. Fairman, American Constitutional Decisions 31 (rev. ed. 1950); 1 P. Freund, A. Sutherland, M. Howe \& E. Brown, Constitutional Law 24 (3d ed. 1967); L. Friedman, A History of American Law 301 (1973); C. E. Hughes, The Supreme Court of the United States 89 (1928); W. Lockhart, Y. Kamisar \& J. Choper, Constitutional LAw 7 n.f (5th ed. 1980); J. NOWAK, R. ROTUNDA \& J. YOUng, HaNDBOOK OF Constitutional LAw 114 n.11 (1978); T. Poweld, Vagaries and Varieties in Constitutional IntERPRETation 20 (1956); B. Schwartz, The Law in America 49 (1974); L. Tribe, American Constitutional Law 2 (1978). See also J. Thayer, John Marshall 72 (1901).

- See, e.g., H. Abraham, The Judicial Process 303-04 (4th ed. 1980); E. Corwin, Court Over Constitution 67, 69 (1938); 2 W. Crosskey, Politics and the Constitution in the History of the United States 978 (1953); R. E. Cushman \& R. F. Cushman, Cases in Constitutional Law 17 (3d ed. 1968); 1 C. Haines, The Role of the Supreme Court in American Government and Politics 1789-1835, at 120 (1944); A. Mason \& W. Beaney, American Constitutional Law 20-21 (6th ed. 1978); W. Mendelson, The American Constitution and the Judicial. Process 6 (1980); C. Pritchett, The Ambrican Constitution 128 (3d ed. 1977); M. Shapiro \& R. Tresolini, American Constitutional Law 74 (5th ed. 1979); C. Swisher, American Constitutional Development 107 (1943); S. Wasby, The Supreme Court in the Federal Judicial System 39 (1978); Mrson, Preface to J. Cotton, The Constitutional Decisions of John Marshall, xiv-xv (reprint 1969). See also C. Haines, The American Doctrine of Judicial Supremacy 341-42, 567 (2d ed. 1959); B. Wright, Growth of American Constitutional Law 38 (1942).

s See, e.g., 3 A. Beveridge, The Life of John Marshall 131-32 n.2 (1919); H. Сoмmager, Majority Rule and Minority Rights 47-48, 89 n.43 (1943); H. Hockett, The Constitutional History of the United States 1776-1826, at 308 (1939); A. Mclaughlin, A Constitutional History of the United States 317 (1935); C. Warren, Congress, the Constitution, and the Supreme Court 135 n.1, 273 (1925); 2 C. Warren, The Supreme Court in United States History 533 n.2 (rev. ed. 1926). See also D. Fehrenbacher, The Dred Scott Case 223 (1978); A. Kelly \& W. Harbison, The American Constitution 218 
learns from compilations prepared by the Court's own reporter ${ }^{8}$ and by the Library of Congress. ${ }^{7}$

Within the last three decades, however, some very distinguished legal scholars have begun to write of a second Marshall Court decision that held a provision of a congressional act unconstitutional-the obscure 1809 case of Hodgson $v$. Bowerbank. ${ }^{8}$ Henry Hart and Herbert Wechsler apparently were the first to notice the implications of the case. Their discussion of Hodgson appears in their commentary on National Mutual Insurance Co. $v$. Tidewater Transfer Co., ${ }^{9}$ in which Chief Justice Fred Vinson, dissenting, cited Hodgson. ${ }^{10}$ Concerning the earlier case, Hart and Wechsler noted that "the Court in a short opinion by Marshall declared unconstitutional a provision of the First Judiciary Act purporting to give the federal courts jurisdiction in 'all suits' in which an alien was a party."11 A similar interpretation was offered by Charles Alan Wright:

The 1789 Judiciary Act purported to extend jurisdiction to all suits in which an alien is a party. The Court at a very early date held that this was unconstitutional insofar as it might permit suit in federal courts between two aliens, while the Constitution only authorizes jurisdiction of suits between a citizen of a state and an alien. ${ }^{12}$

This revisionist interpretation of Hodgson was initially confined to works on federal courts and jurisdiction. Recently, however, it has begun to appear in casebooks on constitutional law. Edward L. Barrett and William Cohen, in the most recent edition of their casebook, write:

(5th ed. 1976).

- See 131 U.S. app., at ccxxxy-ccxxxvii (1889) (but not citing Dred Scott).

- See Legislattve Rererence Service, Library of Congress, Provisions of Federal Law Held Unconstitutional by the Supreme Court of the United States 2, 87-91, 13031, 139, 141 (1936); Congressional Research Service, Library of Congress, The ConstiTUTION OF THE UNITEd STATES: ANALysis AND INTERPRETATION 1597-1619 (1973) [hereinafter cited as CRS].

9 U.S. (5 Cranch) 303 (1809).

- 337 U.S. 582 (1949).

10 Id. at 637 .

11 H. Hart \& H. Wechsler, The Federal Courts and the Federat System 372 (1953), reprinted in P. Bator, P. Mishkin, D. Shapiro \& H. Wechsler, Hart \& Wechsler's The Federal Courts and the Federal System 417 (2d ed. 1973) [hereinafter cited as Hart \& WECHSLER].

12 C. Wright, Handeook of the Law op Federal Courts 70 (1963), reprinted in id. at 93 (3d ed. 1976). A footnote identifies the case cited as Hodgson. Id. at $70 \mathrm{n} .9$, reprinted in id. at 93 n.10 (3d ed. 1976). 
During the tenure of Marshall as Chief Justice, the only other case [besides Marbury] holding an Act of Congress unconstitutional was the obscure decision in Hodgson v. Bowerbank . . . . In a brief opinion, Marshall held a provision of the Judiciary Act of 1789 unconstitutional in conferring jurisdiction on federal courts to try suits between aliens. ${ }^{13}$

And Gerald Gunther, in the most recent edition of his casebook, observes that "[a]fter Marbury, the Court did not hold another major federal law unconstitutional until the controversial and illfated decision in Dred Scott v. Sandford."14 Gunther's statement pointedly leaves open the possibility that the Court in this interval held a "minor" federal law unconstitutional. Although the statute at issue in Hodgson was the Judiciary Act of 1789-the same "major" federal law at issue in Marbury -it is likely that Gunther intends an oblique reference to Hodgson.

Proponents of this reinterpretation of Hodgson also include Leonard Baker, the author of a recent biography of John Marshall:

In an 1809 case, Hodgson and Thompson v. Bowerbank and Others, Marshall ruled expressly on the question whether Congress can broaden the Constitution by legislation. The case involved two aliens, and Congress had given the Circuit Courts jurisdiction over cases involving aliens. . . . Asserting that the Constitution did not authorize such jurisdiction, he declared that "the objection was fatal."1s

The purpose of this historical note is to determine whether we are justified in understanding Hodgson as an instance in which the Marshall Court held unconstitutional a provision of a congressional act. The Hodgson case is not very important in itself, but the spreading acceptance of the reinterpretation of the case potentially affects our understanding of the history of judicial review and even of what it means for a court to hold a law "unconstitutional."

What can we learn from a careful reading of Chief Judge William Cranch's report of the Hodgson case? ${ }^{16}$

18 E. BarretT \& W. Cohen, Constitutional Law 34 n.c (6th ed. 1981).

16 G. Gunther, Constitutional Law 15 n.* (10th ed. 1980) (emphasis added). Compare Gunther's language in the ninth edition. G. Gunther, Constitutional Law 15 n.* (9th ed. 1975) (omitting qualifier "major").

18 L. Baker, John Marshazl: A Life in the Law 551 (1974) (footnotes omitted).

16 The complete report is as follows: 
Evidently Bowerbank and others, British subjects, brought suit against Hodgson and Thompson in the United States Circuit Court for the District of Maryland. The circuit court, comprised of Supreme Court Justice Samuel Chase and District Judge James Houston, accepted "late of the district of Maryland" as a sufficient description of the defendants' status, heard the suit, and decided in favor of the plaintiffs. ${ }^{17}$

Hodgson and Thompson then carried the case to the Supreme Court on a writ of error. ${ }^{18}$ Their counsel, Luther Martin, ${ }^{19}$ argued that the circuit court did not have jurisdiction to hear the suit, because the complaint established that the plaintiffs below were aliens but did not allege that the defendants were citizens of one of the United States. ${ }^{20}$ Counsel for Bowerbank, Charles Lee, ${ }^{21}$ replied by arguing that section 11 of the Judiciary Act, ${ }^{22}$ standing alone,

\section{Hodgson \& Thompson}

v.

Bowerbank and others

ERROR to the Circuit Court for the district of Maryland. The defendants below were described in the record as "late of the district of Maryland, merchants," but were not stated to be citizens of the state of Maryland. The plaintiffs were described as "aliens and subjects of the king of the United Kingdom of Great Britain and Ireland."

Martin contended, that the courts of the United States had not jurisdiction, it not being stated that the defendants were citizens of any state.

C. Lee, contra. The judiciary act gives jurisdiction to the circuit courts, in all suits in which an alien is a party. Laws U.S. vol. 1. p. 55 . $\S 11$.

Marshall, Ch. J. Turn to the article of the constitution of the United States, for the statute cannot extend the jurisdiction beyond the limits of the constitution.

(The words of the Constitution were found to be "between a state, or the citizens thereof, and foreign states, citizens or subjects.")

The court said the objection was fatal.

The record was afterwards amended by consent.

9 U.S. (5 Cranch) 303, 303-04 (1809).

17 Id. at 303.

18 Id.

19 Martin was a Maryland delegate to the Constitutional Convention, Attorney General of Maryland, and one of the most distinguished members of the Supreme Court bar. See $P$. Clarkson \& R. Jett, Luther Martin of Maryland 41, 69, 273-85 (1970); H. Cummings \& C. McFarland, Federal Justice 70 (1937); 12 Dictionary of American Biography 343-45 (D. Malone ed. 1933); J. Goebel, 1 History of the Supreme Court of the United States 215 (1971).

${ }^{20}$ See 9 U.S. (5 Cranch) at 303; supra note 16.

${ }^{21}$ Lee was one of the leading Federalist lawyers of the time, had served as Attorney General under Presidents Washington and Adams, and had been Marbury's counsel in Marbury v. Madison. See H. Cummings \& C. McFarland, supra note 19, at 46-47, 55, 70; 11 Dictionary of AmERican BIOGRAPHY, supra note 19, at 101-02; J. GoEBEL, supra note 19, at $582,683$.

22 Section 11 read in full:

And be it further enacted, That the circuit courts shall have original cognizance, concurrent with the courts of the several States, of all suits of a civil nature at common 
required only that one party to the suit be an alien, and that the circuit court then had jurisdiction regardless of the status of the other parties. ${ }^{23}$

Chief Justice Marshall replied to Lee's argument with the instruction to "[t]urn to the article of the constitution of the United States, for the statute cannot extend the jurisdiction beyond the limits of the constitution."24 Marshall's instruction was no mere rhetorical flourish, for apparently someone then consulted the Constitution and read the words of article III, section 2: "The judicial Power shall extend . . . to Controversies . . . between a State, or the Citizens thereof, and foreign States, Citizens or Subjects."

The Court then announced that "the objection was fatal."2s The circumstances indicate that the objection must have been that raised by Martin-that the record was inadequate to establish the jurisdiction of the circuit court-and not, as the revisionists suppose, an objection by Marshall to the constitutionality of the Judiciary Act. This conclusion is reinforced by the fact that the record was afterward amended; ${ }^{26}$ had the provision been held unconstitutional, there would have been no possible amendment of the record that could have materially affected the disposition of the case.

There can be no doubt that the meaning of the Court's decision was that, irrespective of the literal wording of the Judiciary Act, a circuit court could not take jurisdiction of a case unless it appeared on the record that one of the parties was a citizen of a state. As Chief Justice Vinson said, "the Court refused to give literal effect" to the alien clause. ${ }^{27}$ It is probably true to say, as David $P$. Currie does, that "the original statute granting jurisidiction whenever an alien was a party was narrowed on constitutional grounds";28 or as Felix Frankfurter and James M. Landis did, that it was "confined by judicial interpretation";"29 or as Charles Warren

law or equity, where the matter in dispute exceeds, exclusive of costs, the sum or value of five hundred dollars, and the United States are plaintiffs, or petitioners; or an alien is a party, or the suit is between a citizen of the State where the suit is brought, and a citizen of another State.

Judiciary Act of 1789, ch. 20, $\$ 11,1$ Stat. 73, 78 (emphasis in original). The current alien jurisdiction provisions are found at 28 U.S.C. $\$ 1332(a)(2) \&(3)$ (1976).

${ }^{23}$ See 9 U.S. (5 Cranch) at 304; supra note 16.

249 U.S. (5 Cranch) at 304.

25 Id.

26 Id.

${ }^{27}$ National Mut. Ins. Co. v. Tidewater Transfer Co., 337 U.S. 582, 637 (1949) (Vinson, C.J., dissenting).

28 D. Currie, Federal Courts 447 (2d ed. 1975).

20 F. Frankpurter \& J. Landis, The Business of the Supreme Court 8 n.15 (1927). 
did, that the Court "read into [section 11] a limitation which it did not actually contain." All of this demonstrates what the Congressional Research Service calls "the meticulous care manifested [by the Court] in this case."31 None of these authorities, however, concludes that in so acting the Court held any part of the section unconstitutional.

One of the strategies available to the Court to avoid passing on the constitutionality of an act is to construe the statute narrowly. There is a very fine line between a ruling that a statute does not apply in particular cases and a ruling that the statute is unconstitutional insofar as it applies to such cases. If a more restrictive, less literal construction of a statute constitutes a holding of unconstitutionality, then there was such a holding in Hodgson. But if that is so, Hodgson was not the first case in which the disputed clause of section 11 was held to be unconstitutional. ${ }^{32}$

If narrow statutory construction or the "reading into" the statute of a constitutional limitation is not alone sufficient to amount to a holding of unconstitutionality, then the Hart-Wechsler-Wright reinterpretation of Hodgson depends upon one of two possibilities. Either Congress must have intended to extend the jurisdiction of the federal courts beyond the limits set by article III, or there must be no way to read the statute other than as so extending the jurisdiction.

Hart and Wechsler write of the "attempt" of Congress to confer extraconstitutional jurisdiction, ${ }^{33}$ and Currie says that Congress "tried" to give it." Wright, passage, ${ }^{36}$ use forms of the more ambiguous word "purport." To "attempt" and to "try" clearly connote intention; to "purport" may convey intention, but also may signify the meaning inferred by the reader or listener, regardless of the user's intention. To some extent, at least, the revisionist interpretation of Hodgson depends upon a particular understanding of what Congress intended when it passed section 11. The inquiry thus turns to Congress's

so Warren, New Light on the History of the Judiciary Act of 1789, 37 Harv. L. REv. 49, 79 (1923).

31 CRS, supra note 7, at 746 .

32 See infra notes 50-57 and accompanying text.

33 HART \& WeChSLER, supra note 11, at 889, reprinted in id. at 1061 (2d ed. 1973).

34 D. CuRrie, supra note 28 , at 182.

${ }^{35} \mathrm{C}$. Wright, supra note 12 , at 17,70 , reprinted in id. at 20,93 (3d ed. 1976) ("purported").

${ }^{36}$ Hart \& Wechsler, supra note 11 , at 372 , reprinted in id. at 417 (2d ed. 1973) ("purporting"). 
intent.

\section{II}

The First Congress passed the Judiciary Act of 1789 during its first session. ${ }^{37}$ Unfortunately, the history of that Act is shrouded in mystery because the debates of the Senate were then secret, and amendments made in the Senate and House of Representatives were not recorded in any detail. ${ }^{38}$ Nevertheless, there is some basis for inferring Congress's intent in passing the disputed clause.

The Senate achieved a quorum to do business on April 6, 1789, and the next day appointed a committee "to bring in a bill for organizing the judiciary of the United States."3s Just over two months later, the committee completed a bill "to establish the judicial courts of the United States."40 Although Richard Henry Lee reported the bill, Oliver Ellsworth of Connecticut, a distinguished expert on the judiciary, was its principal draftsman. ${ }^{41}$ There is no evidence to suggest why Ellsworth's bill conferred jurisdiction on the circuit courts in suits where "an alien is a party"42 rather than simply reciting the more restrictive language of the Constitution. There is evidence, however, of what he thought his words meant. On April 30, 1789, he wrote to Judge Richard Law of Connecticut:

The following are the outlines of a judiciary system con-

27 Ch. 20, 1 Stat. 73 (1789) (codified and amended in scattered sections of 28 U.S.C. (1976)); J. GoEBrL, supra note 19, at 507; Warren, supra note 30 , at 49, 131.

ss See Warren, supra note 30 , at $49 \&$ n.2.

30 1 Annars of Cong. 18 (J. Gales ed. 1789). Ten of the Senate's 20 members-John Langdon, Caleb Strong, Oliver Ellsworth, William Samuel Johnson, William Paterson, Robert Morris, Richard Bassett, George Read, Pierce Butler, and William Few-had been at the Convention. W. Maclay, Sketches of Debate in the First Senate of the United States 1 (1880). Of these, Ellsworth, Paterson, Strong, Bassett, and Few served on the committee to draft the Judiciary Bill. 1 ANnals of Cong. 18 (J. Gales ed. 1789). At least two committee members-William Maclay and Richard Henry Lee-were strong states' rights men who opposed the creation of a separate federal judiciary. See Warren, supra note 30, at 109, 114.

40 1 Annals of Cong. 47 (J. Gales ed. 1789).

11 W. Brown, The Life of Olrver Ellsworth 184-97 (1905); J. GokBer, supra note 19, at 459-60; W. MACLAY, supra note 39, at 90; Warren, supra note 30, at 59-60. Ellsworth had been one of the most active members of the Constitutional Convention, see M. FarRand, The Framing of the Constitution of the United States 124, 200 (1913), and a member of its committee of detail, $i d$. at 122, 124; J. GokBRL, supra note 19, at 232 . He was previously a judge of the Supreme Court of Connecticut, M. FARRAND, supra, at 34-35, and after serving in the Senate he was Chief Justice of the United States, J. GokBki, supra note 19, at 749. The judiciary was Ellsworth's special field of expertise, and he apparently drafted two supplementary laws during the first session of Congress, in addition to the Judiciary Act. See W. Brown, supra, at 197.

13 Judiciary Act of 1789 , ch. $20, \S 11,1$ Stat. 73,78 (1789) (current version at 28 U.S.C. $\S 1332(a)(2)(1976)) ;$ see supra note 22. 
templating before a committee of the Senate.

That the United States be divided into three circuits. That a court be holden twice annually in each State .... . This court to . . . have original jurisdiction in law and equity, in controversies between foreigners and citizens . . . .43

How it happened that Ellsworth was able to use unambiguous language to describe the system he was designing even while inserting into the draft bill words that would later occasion confusion is something that will probably never be explained. But it seems clear that his intention was to extend the jurisdiction of the circuit courts to precisely the same class of cases involving aliens as the Constitution brought within the federal judicial power.

Most of the debate on the Judiciary Act centered on the very idea of creating inferior federal courts and the asserted invasion of state court jurisdiction that would result." Although states' rights champions jealously resisted the bill, the words of the alien clause of section 11 passed unchallenged (at least insofar as we have any record). Even Pennsylvania's Senator William Maclay, a member of the committee who opposed virtually every provision of Ellsworth's draft and who delighted in finding instances "where Ellsworth in his diction had varied from the Constitution," object on the record to the wording of the disputed clause.

In the recorded debates of the House of Representatives, only one member objected to giving the circuit courts jurisdiction when an alien was a party to a suit. Representative Michael Stone of Maryland complained that "the Senate, by this bill, have given us this construction: foreigners may sue and be sued in all the States. This has already been done; do gentlemen now contend, that these suits shall be exclusively in the Continental Courts?"46 Even here, Stone assumed that cases involving foreigners would involve citizens as the adversary parties. Indeed, his objection was precisely that the federal judiciary would be insufficiently solicitous of the rights of citizens in their controversies with foreigners. It does not seem to have occurred to any of the participants in the debates that the federal alienage jurisdiction would include a controversy in which no domestic citizen was a party.

4s Quoted in W. Brown, supra note 41, at 188-89.

44 See Warren, supra note 30 , at 65-67, 81-82, 96-97, 109, 123, 127.

4 W. MACLAX, supra note 39 , at 90.

16 1 Annals of Cong. 857 (J. Gales ed. 1789). 
If the wording of the alien clause of section 11 is ambiguous, Congress seems to have been the victim of Ellsworth's literary style. Discussing the jurisdictional provisions in the Judiciary Act, Edmund Randolph ${ }^{47}$ complained in a letter to Congressman James Madison that "[t]he jurisdiction is inartificially untechnically and confusedly worded. Would it not have been sufficient to have left this point upon the constitution itself?"48 Randolph did not accuse Ellsworth of any unconstitutional design; rather he complained of Ellsworth's clumsiness in executing a constitutional one.

It is possible, of course, that Ellsworth's grammar was even worse than his diction. He actually may have intended the part of the paragraph following "the United States are plaintiffs or petitioners"49 to mean that a case must be between an alien or a citizen of one state on one side, and a citizen of a[nother] state on the other side. Mere inattention or imprecision thus may have caused the provision to be grammatically problematic, albeit constitutionally impeccable in its intent. Because the Supreme Court never adopted this reading, however, a thesis built on Ellsworth's faulty grammar cannot explain what the Court did respecting the alien clause. In theory, however, the thesis provides a way to deny that Congress intended to transgress constitutional limits.

A fair interpretation of the available evidence is that Congress intended to do no more than to distribute among the three tiers of the new federal judiciary the bulk of the constitutionally ordained judicial power of the United States. Whether through a lapse of imagination, a failure of literary style, or some other cause, Congress expressed that intent inexactly, using words that could, but did not necessarily, bear an interpretation that could carry them beyond the constitutional pale.

\section{III}

The Hart-Wechsler-Wright revisionist interpretation of $\mathrm{Hodg}$ son's significance does not consider the case law context of the decision. Read in context, Hodgson is but one of a series of cases in which the Court either construed section 11 so as to make it constitutional, or embraced the idea that statutes should be construed

47 Randolph had been a leading member of the Constitutional Convention and was about to become the nation's first attorney general. See H. Cummings \& C. McFardand, supra note 19, at 18-19; M. FARRAND, supra note 41, at 124, 199.

4s Letter from Edmund Randolph to James Madison (June 30, 1789), reprinted in 12 Papers of James Madison 274 (C. Hobson \& R. Rutland eds. 1979).

15 See supra note 22 . 
to avoid conflicts with "higher" law.

The first case in which the alien clause of section 11 was at issue was Mossman $v$. Higginson, ${ }^{50}$ decided in 1800 , prior to John Marshall's tenure on the Court. Higginson, a merchant and a British subject, sued Mossman, the executor of the estate of a deceased debtor. The complaint asserted that Higginson was an alien, but said nothing of Mossman's citizenship. ${ }^{51}$ The case went to the Supreme Court on a writ of error from the Circuit Court for the District of Georgia. ${ }^{82}$ Mossman was represented by Jared Ingersoll, ${ }^{\text {,s }}$ who argued that "[ $t]$ he judiciary act was only intended to carry the constitution into effect, and cannot amplify, or alter its provisions. The constitution nowhere gives jurisdiction (nor has any judge ever countenanced the idea) in suits between alien and alien."

The Court evidently found Ingersoll's argument convincing. Its per curiam opinion held that

the eleventh section of the judiciary act can and must receive a construction consistent with the constitution. It says, it is true, in general terms, that the circuit court shall have cognisance of suits "where an alien is a party;" but as the legislative power of conferring a jurisdiction on the federal courts, is in this respect, confined to suits between citizens and foreigners, we must so expound the terms of the law, as to meet the case, "where, indeed, an alien is one party," but a citizen is the other. ${ }^{.85}$

This case is an almost exact parallel of Hodgson. The plaintiff below in each case was a British subject, and each stated so in his complaint. The defendant in each case objected to the federal circuit court taking jurisdiction because the complaint did not affirmatively allege that the defendant was a citizen of a state. In each case the Supreme Court ruled that the objection was fatal. What distinguished Mossman, besides its relatively early date, is the Court's clear statement of what it was doing-construing the alien clause of section 11 to find it constitutional. ${ }^{\text {se }}$ In so holding, it fol-

so 4 U.S. (4 Dall.) 12 (1800).

s1 Id. at 12.

${ }^{82} I d$.

ss Ingersoll had been a Pennsylvania delegate to the Constitutional Convention. 3 ThE Records of the Federal Convention of 1787, at 558 (M. Farrand rev. ed. 1937).

st 4 U.S. (4 Dall.) at 13.

ss Id. at 14. The Court's opinion began by noting that "[t]he decisions on this subject govern the present case." Id.

so See Currie, The Constitution in the Supreme Court: 1789-1801, 48 U. CHI. L. REv. $819,821,851-53$ (1981). 
lowed a rule that has become a fundamental maxim of constitutional law: the Court interprets ambiguous statutes with the presumption that Congress intended to enact constitutionally sound legislation, and, wherever possible, narrows the literal scope of congressional language in accordance with this presumption. ${ }^{.7}$

The Court in Hodgson seems to have followed this rule of construction, and to assert otherwise is to claim for Hodgson double significance: not only did the Court hold an act of Congress unconstitutional; it also overruled, albeit tacitly, a previous decision. The report of Hodgson is not adequate to sustain such a reading.

Although there is no pre-Hodgson Marshall Court case endorsing the general rule of construction followed in Mossman, the 1804 admiralty case of Murray v. The Schooner Charming Betsy ${ }^{\mathrm{ss}}$ shows that Marshall was open to this rule. In that case, he endorsed the proposition that "an act of congress ought never to be construed to violate the law of nations, if any other possible construction remains." ${ }^{59}$ If Marshall was willing to construe a federal statute as consistent with international law whenever possible, might he not be assumed to be willing to do the same with respect to the Constitution, the "superior paramount law, unchangeable by ordinary means"?

Another case between Mossman and Hodgson brought the alien clause of section 11 before the Marshall Court. In Montalet $v$. Murray, ${ }^{\text {s1 }}$ both original parties to the suit were aliens. This fact was made the basis of the jurisdictional objection, and section 11 was cited in support of that objection. ${ }^{82}$ Moreover, according to the report, "the court was unanimously of the opinion that the courts of the United States have no jurisdiction of cases between aliens. ${ }^{38 s}$ When counsel suggested that the alienage of both parties

${ }^{37}$ For a later elaboration of this rule, see Parsons v. Bedford, 28 U.S. (3 Pet.) 433, 448 49 (1830) (Story, J.) ("No court ought, unless the terms of an act rendered it unavoidable, to give a construction to it, which should involve a violation, however unintentional, of the constitution."). See also Justice Story's statement of this rule in United States v. Coombs, 37 U.S. (12 Pet.) 72, 76 (1838):

[I]f the section admits of two interpretations, one of which brings it within, and the other presses it beyond, the constitutional authority of congress, it will become our duty to adopt the former construction; because a presumption never ought to be indulged, that congress meant to exercise or usurp any constitutional authority, unless that conclusion is forced upon the court by language altogether unambiguous.

ss 6 U.S. (2 Cranch) 64 (1804).

Id. at 118.

co Marbury v. Madison, 5 U.S. (1 Cranch) 137, 177 (1803).

81 U.S. (4 Cranch) 46 (1807).

62 Id. at 47 .

ss Id. (emphasis in original). 
was not conclusively shown upon the record, Chief Justice Marshall replied "that if it did not appear upon the record that the character of the original parties would support the jurisdiction, that objection was equally fatal, under the uniform decisions of this court." The "uniform decisions" presumably included Mossman.

Moreover, the Marshall Court shortly after Hodgson applied the rule of narrow construction to another section of the Judiciary Act. In Owings $v$. Norwood's Lessee, ${ }^{\mathrm{es}}$ the Court of Appeals of Maryland had ruled against a defendant in an ejectment action, who had incidentally drawn upon the possible claim of a third party based on Jay's Treaty. Section 25 of the Judiciary Act authorized reexamination by the Supreme Court of the final judgment of the highest state court in any suit "where is drawn in question the construction of any clause of a treaty, and the decision is against the right claimed under such clause of the treaty." opinion of the Court, Chief Justice Marshall said that the Court did not have the power to review the case, notwithstanding the wording of section 25, because Owings's case did not arise under the treaty within the meaning of the Constitution. Marshall declared that "[t]he 25th section of the judiciary act must be restrained by the constitution, the words of which are, 'all cases arising under treaties." "87 The Court thus held that the scope suggested by the words of section 25 was narrowed by reading section 25 along with article III. This was neither more nor less than the Court did in Hodgson with respect to section 11. If it is correct to say that some aspect of section 11 was held unconstitutional in Hodgson, then by the same logic, some aspect of section 25 was held unconstitutional in Owings. Yet that interpretation has nowhere been asserted.

When Hodgson was decided, then, it had long been settled that the circuit courts did not have jurisdiction over cases in which it was not shown that one party was a citizen of one of the United States. Moreover, both the Marshall Court and its predecessor had embraced the doctrine of construing ambiguous statutes consistently with the Constitution. In this light, it seems that Hodgson did no more than rectify an aberrant circuit court decision, proba-

64 Id.

9 U.S. (5 Cranch) 344 (1809).

Id. at 345 (paraphrasing 1 Stat. 73, 85-86 (1789) (current version at 28 U.S.C. $\S$ 1257(1) (1976)).

67 U.S. (5 Cranch) at 347 (emphasis omitted). 
bly a mere oversight on the part of the circuit judges, and bring about a result compatible with the Court's previous decisions."

\section{IV}

The assertion that there was a holding of unconstitutionality in Hodgson is of very recent origin. Neither Chancellor James Kent nor Justice Joseph Story, in their classic commentaries on American law and the Constitution, attributed to Hodgson the significance accorded it by the Hart-Wechsler-Wright thesis. Kent treated the issue of alien-versus-alien jurisdiction under the disputed clause as settled by Mossman ${ }^{80}$ and reaffirmed by Montalet and Hodgson. ${ }^{70}$ Story, in discussing the same point, did not mention these cases, but cited as authority the 1829 case of Jackson $v$. Twentyman. ${ }^{21}$ The Jackson report shows that the Court was aware of Hodgson during its deliberations: counsel for the plaintiff in error had cited it as precedent..2 The issue was the same as in Mossman and Hodgson: the plaintiff below was described on the record as a British subject, and the citizenship of the defendants was not averred, but the circuit court nevertheless heard the suit. ${ }^{73}$ The Supreme Court's opinion reversing this decision is important. If the Marshall Court had already held the alien clause unconstitutional to the extent it permitted jurisdiction where neither party to a suit was a citizen of a state, the members of the Court should have known it. And if they knew that to be the case, they might reasonably be expected to have said so. Instead, the Court held that section 11

must be construed in connection with, and in conformity to,

- There is, in fact, good reason to believe that the jurisdictional objection had not been raised at the circuit court level, but was first made on appeal. The Supreme Court Justice who sat with the district judge on the circuit court in Maryland was Samuel Chase, who had been on the Court when it decided Mossman, see Currie, supra note 56, at 820, and, who therefore was surely aware of the precedent.

- 1 J. Kant, Commgntaries on Amgrican Laf 323 (New York 1826) (footnote omitted):

The judiciary act of 1789 , sec. 11 , gives jurisdiction to the circuit court where an alien is a party; and it was decided in Mossman v. Higginson, that the jurisdiction was confined to the case of suits between citizens and foreigners, and did not extend to suits between alien and alien; and that if it appeared on the record that one party was an alien, it must likewise appear affirmatively, that the other party was a citizen.

70 Id. at 323-24.

71 3 J. Story, Commentarirs on the Constitution of the Unitrd Statzs 571 (Boston 1833) (citing 27 U.S. (2 Pet.) 136 (1829)).

7227 U.S. (2 Pet.) at 136.

${ }^{73} \mathrm{Id}$. 
the constitution of the United States. That, by the latter, the judicial power was not extended to private suits, in which an alien is a party, unless a citizen be the adverse party. It was indispensable, therefore, to aver the citizenship of the defendants, in order to show, on the record, the jurisdiction of the court. The omission so to do was fatal, and according to the known course of the decisions of the court, the judgment of the circuit court must be reversed, for want of jurisdiction. ${ }^{74}$

The language of the Court's opinion recalls that in Mossman; ${ }^{78}$ once again, the Court construed the disputed clause in conformity with the Constitution. If Hodgson overruled Mossman on that point, as it must have done if it comprised a holding of unconstitutionality, then Jackson overruled Hodgson, because Jackson restored the rule of Mossman. This is a rather tortured reading of these cases. The argument that the Court simply forgot what it had done in previous cases would be unacceptable even if the report did not show that counsel had cited the previous cases. Defenders of the Hart-Wechsler-Wright thesis must answer this question: given that Marshall pronounced the alleged holding of unconstitutionality in Hodgson, and that Marshall was still Chief Justice when Jackson was decided, why is there no acknowledgment of the overruling of the earlier case?

Hodgson has been cited in many federal court opinions since the Marshall era, including opinions of the Supreme Court.. ${ }^{76}$ It continues to be cited as authority for "the requirement that diversity jurisdiction must be specifically pleaded," limitation on congressional power to define the jurisdiction of federal courts $^{78}$ and the proposition that federal courts do not have jurisdiction over suits between aliens. ${ }^{79}$ But it has never been cited in a reported federal court opinion as an instance where the Supreme Court held an act of Congress to be unconstitutional.

24 Id.

${ }^{75}$ See 4 U.S. (4 Dall.) at 14.

7s See Romero v. International Terminal Operating Co., 358 U.S. 354,390 n.1 (1959) (separate opinion of Brennan, J.); National Mut. Ins. Co. v. Tidewater Transfer Co., 337 U.S. 582, 637 (1949) (Vinson, C.J., dissenting); Shaw v. Quincy Mining Co., 145 U.S. 444, 447 (1892); Marshall v. Baltimore \& O.R.R., 57 U.S. (16 How.) 314, 340 (1853) (Daniel, J., dissenting); McNutt v. Bland, 43 U.S. (2 How.) 9, 22 (1844) (Daniel, J., dissenting).

${ }^{77}$ Gavelek v. Coscol Petroleum Corp., 491 F. Supp. 188, 190 n.2 (E.D. Mich. 1979); see also Hodas v. Lindsay, 431 F. Supp. 637, 640 (S.D.N.Y. 1977) (the "essential elements of diversity jurisdiction must be affirmatively alleged in the pleadings").

${ }^{78}$ Verlinden B.V. v. Central Bank of Nigeria, 647 F.2d 320, 324 (2d Cir. 1980).

70 Field v. Volkswagenwerk AG, 626 F.2d 293, 296 n.1 (3d Cir. 1981). 
Thus far in this inquiry, I have accepted the assumption that the words of Chief Justice Marshall in Hodgson constituted an informal opinion of the Court. The Hart-Wechsler-Wright thesis rests on this assumption; it may be false, however.

It was the habit of Chief Judge Cranch, at least throughout the fifth volume of his reports, to record the colloquy between the Justices and counsel during oral argument. ${ }^{30}$ The status of this colloquy is uncertain at best, and very often it shows a Justice arguing a position at odds with his final opinion. Cranch usually introduced the opinion of the Court with the formula, "Marshall, Ch. J., delivered the opinion of the court," opinion, "the Court said . . .."18 The practice was not invariable, however, and so it is not conclusive in this case. In the Hodgson report, Marshall's statement is followed by the information that "the words of the constitution were found to be . . .,"ss indicating that someone other than Marshall had, in response to his direction, turned to the article of the Constitution and read it aloud to the Court. This fact suggests that Marshall's statement was not the opinion of the Court but part of a dialogue with Charles Lee. Moreover, the reading of the Constitution is followed by a sentence beginning, "[t]he Court said . . .," Cranch's formula for introducing a per curiam opinion.

\section{VI}

The weight of the evidence is against the position of Professors Hart, Wechsler, and Wright that there was a holding of unconstitutionality in Hodgson v. Bowerbank. First, there is no evi-

so On Cranch as Supreme Court reporter, see generally N. Kramer, Half a Century Past Midnight: The Life and Times of Judge William Cranch 135-50 (unpublished Ph.D. dissertation, Claremont Graduate School, 1978).

s1 See, e.g., Himely v. Rose, 9 U.S. (5 Cranch) 313, 316 (1809); Harrison v. Sterry, 9 U.S. (5 Cranch) 289, 298 (1809); United States v. Arthur, 9 U.S. (5 Cranch) 257, 261 (1809).

${ }^{82}$ See, e.g., Whelan v. United States, 11 U.S. (7 Cranch) 112, 112 (1812); The Schooner Rachel v. United States, 10 U.S. (6 Cranch) 329, 330 (1810); Logan v. Patrick, 9 U.S. (5 Cranch) 288, 288-89 (1809). Cf. Sloop Sally v. United States, 9 U.S. (5 Cranch) 372, 374 (1809) ("the Court was of opinion that . . ."); Dulany v. Hodgkin, 9 U.S. (5 Cranch) 333, 334 (1809) (". . . the Court . . . Affirmed . . ."); Welsh v. Mandeville 9 U.S. (5 Cranch) 321, 321 (1809) ("The Court refused . . ."); Browne v. Strode, 9 U.S. (5 Cranch) 303, 303 (1809) ("The Court ordered it to be certified, as their opinion, that . . ."); Hope Ins. Co. v. Boardman, 9 U.S. (5 Cranch) 57, 61 (1809) ("The Court . . . decided . . ."). But see Woods v. Young, 8 U.S. (4 Cranch) 237, 238 (1808) ("By the Court.") (unique example of this form).

ss 9 U.S. (5 Cranch) at 304. See supra note 16.

* Id. 
dence that Congress intended in section 11 to extend the jurisdiction of the federal courts beyond the constitutional limits of the judicial power of the United States. Neither the author of the Act, nor any participant in the debates-including the most vocal opponents of the Act-ever suggested such an intent. Second, the disputed clause already had been the subject of litigation before the Supreme Court and had been construed so as to make it wholly constitutional. Such a rule of construction was consistent with the way the Court handled other ambiguous sections of the Judiciary Act. Third, the Court in construing the same clause as constitutional in a subsequent case, decided under the same Chief Justice and with the Hodgson opinion cited in argument, did not admit to overruling, or even distinguishing, Hodgson. Finally, there is no reason to believe that the words alleged to constitute the holding of unconstitutionality are in fact part of the Court's opinion.

The reinterpretation of Hodgson proposed by Professors Hart, Wechsler, and Wright, endorsed by Professors Barrett and Cohen, and implicitly acknowledged by Professor Gunther, cannot be accepted. The case of Hodgson v. Bowerbank should be allowed to return to the obscurity from which it has only recently been resurrected. 